\title{
Advancement in cVEMP's
}

Citation for published version (APA):

van Tilburg, M. J. (2020). Advancement in cVEMP's. [Doctoral Thesis, Maastricht University]. ProefschriftMaken. https://doi.org/10.26481/dis.20200306mt

Document status and date:

Published: 01/01/2020

DOI:

10.26481/dis.20200306mt

Document Version:

Publisher's PDF, also known as Version of record

\section{Please check the document version of this publication:}

- A submitted manuscript is the version of the article upon submission and before peer-review. There can be important differences between the submitted version and the official published version of record.

People interested in the research are advised to contact the author for the final version of the publication, or visit the DOI to the publisher's website.

- The final author version and the galley proof are versions of the publication after peer review.

- The final published version features the final layout of the paper including the volume, issue and page numbers.

Link to publication

\footnotetext{
General rights rights.

- You may freely distribute the URL identifying the publication in the public portal. please follow below link for the End User Agreement:

www.umlib.nl/taverne-license

Take down policy

If you believe that this document breaches copyright please contact us at:

repository@maastrichtuniversity.nl

providing details and we will investigate your claim.
}

Copyright and moral rights for the publications made accessible in the public portal are retained by the authors and/or other copyright owners and it is a condition of accessing publications that users recognise and abide by the legal requirements associated with these

- Users may download and print one copy of any publication from the public portal for the purpose of private study or research.

- You may not further distribute the material or use it for any profit-making activity or commercial gain

If the publication is distributed under the terms of Article $25 \mathrm{fa}$ of the Dutch Copyright Act, indicated by the "Taverne" license above, 


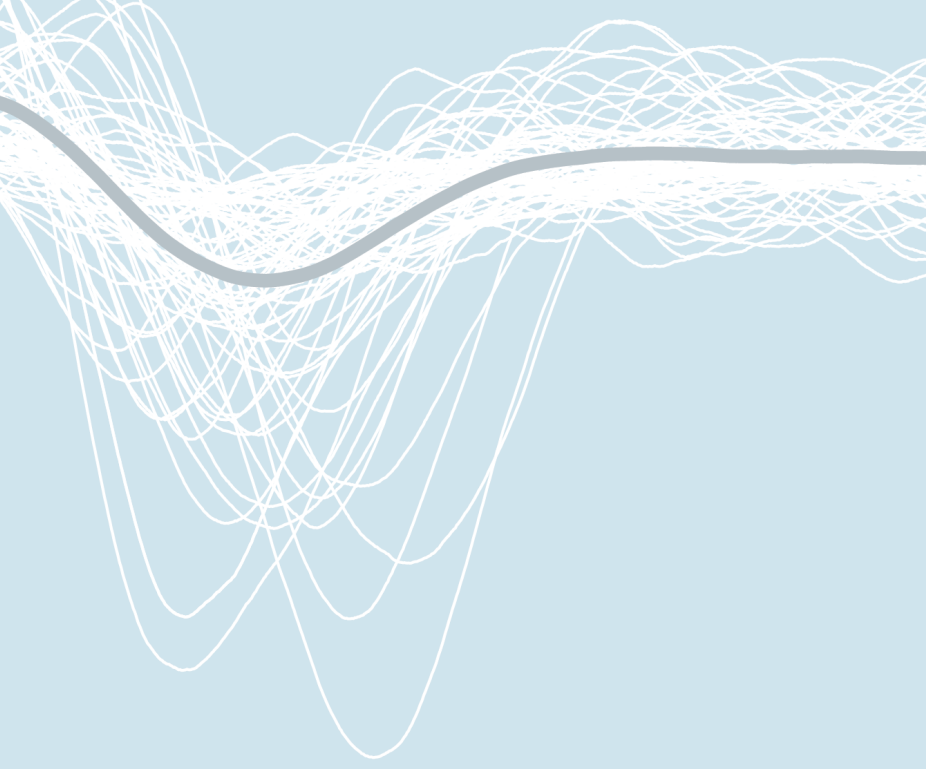

CHAPTER 7

Summary 
128 | Chapter 7 


\section{SUMMARY}

When a dizzy patient consults a specialist the typical evaluation consists of: a careful history, physical examination, an audiogram and perhaps an ENG or imaging. These tests grossly evaluate the middle ear, cochlea and horizontal semicircular canal. The balance organ, however, is much more than just the horizontal semicircular canal, and while much is known about the vestibular apparatus in humans, there are very few tests available to evaluate all parts of the balance organ. This problem is especially relevant in vestibulopathies that do not (always) involve the horizontal semicircular canal such as Meniere's disease and superior canal dehiscence (SCD). The cervical vestibular evoked myogenic potential (CVEMP) is a test that evaluates one of the different parts of the balance organ, namely the saccule.

The cervical vestibular evoked myogenic potential (cVEMP) is a vestibular test that uses sound to elicit a vestibular response resulting in an inhibition in the ipsilateral, contracted sternocleidomastoid (SCM) muscle that can be recorded using EMG electrodes. This inhibition is measured after averaging multiple acoustic stimuli (usually around 200-300 tone bursts) and in healthy people shows the typical waveform. In recent literature the test is gaining attention because it evaluates a part of the balance organ that was previously not possible.

The aim of this thesis was to increase the clinical applicability of the CVEMP and has led to the following questions. In the text below a summarized answer is given to these questions:

- What is the current status of electrophysiological testing for Meniere's disease?

- How can the large intersubject variability in cVEMPs be overcome?

- Using normalized cVEMP's, can we show disease progression in Meniere's disease?

- Is there a method to make cVEMP testing more tolerable?

In chapter two the evaluation of current electrophysiological tests available for Meniere's disease were assessed since this is a vestibulopathy in which cVEMP is mostly used as a diagnostic. Besides VEMP's the electrocochleografy (ECoG) and CHAMP test were evaluated. Electrocochleografy can be useful in the early stages of Meniere's disease, however given

the low negative predicting

value this test is scarce-

ly used clinically. 
The fact that it is not possible to perform the test in hearing loss above 60dB further limits clinical use. Cochlear Hydrops Analysis Masking procedure (CHAMPS) uses the auditory brainstem response (ABR) to assess latency changes that could imply Meniere's disease. Increasing latency would suggest cochlear hydrops which in turn could suggest Meniere's disease. In advanced and active Meniere's patients sensitivity and specificity are described to be 100\%. However if the test is performed in a more diverse Meniere population the sensitivity drops to 31\% and specificity to $28 \%$. Furthermore it is not a vestibular test since it measures cochlear function. The strength of the test is to confirm the Meniere diagnosis in active and severe Meniere's, however as a diagnostic tool its value seems limited. For cVEMP's was found that it is not a plug and play test. Meticulous preparation and execution are essential in order to obtain reliable results. In current literature there are limited studies that describe these methods in detail. Furthermore the underlying physiology and optimal test parameters have not been standardized. More research is needed to determine how to best utilize the CVEMP in diagnosing and monitoring Meniere's disease and possibly other vestibulopaties.

One of the major shortcomings of cVEMP is its dependency on muscle tension, causing a great variability in test outcomes. The most important aim of this thesis was to reduce the influence of muscle contraction on the cVEMP outcome. By correcting for muscle contraction (i.e. normalizing) the variability of the test would be reduced and give a more reliable outcome. In chapter 3 the principle of normalization is applied to CVEMP's and a further study investigates which normalization method is most optimal. These studies are performed in a prospective cohort study in 20 healthy young test subjects. By correcting the output signal for the amount of muscle contraction (=normalization) a significant reduction in variability was achieved in healthy subjects (chapter 3.1). Simply put, normalization uses a coefficient that represents muscle contraction effort. This number is then divided by the outcome of the cVEMP test. By applying normalization the outcome of the CVEMP will more closely represent the saccular function instead of muscle strength.

The process of normalization can be applied in different methods. In other words we described different parameters that play a role in obtaining the normalization coefficient that represent the muscle contraction. In chapter 3.2 we described 3 parameters that influence the coefficient. These are: the timing of the normalization (trace-by-trace of after averaging all 
traces), the type of EMG (RMS or rectified) and the time in which the coefficient is measured (pre-stimulus of during the entire measurement). By using each individual trace during the entire measurement the variability between subjects was substantially reduced. If a testing facility does not have the ability to use extensive signal processing we advise to use the pre-stimulus part of the averaged EMG to obtain a coefficient for normalization.

After demonstrating the effect of normalization the clinical application of cVEMP's was further investigated. In two patient groups consisting of Meniere's patients and vestibular migraine patients the effect of time on cVEMP output was evaluated. The hypothesis was that in the Meniere's group there would be a progressive worsening of the outcome whereas the vestibular migraine groups was anticipated to be more stable over time. Over an average of 2 years the affected side in Meniere's disease showed a significant worsening of both peak to peak amplitude and threshold measurements. The unaffected side remained stable over this time period. In the vestibular migraine group all patients showed stable cVEMP's over time. An important limitation of this study was its retrospective design and the small amount of patients. However each individual patient from both groups showed the same outcome (i.e. significant worsening in Meniere's patients and stable results in vestibular migraine patients). Vestibular migraine was only described recently and it is possible that in the past patients diagnosed with Meniere's disease actually suffered from vestibular migraine. Given this we advise to incorporate CVEMP as a regular test in the vestibular testing battery, so the progression of the test over time can be evaluated.

The last study described in this thesis investigated the improvement of clinical application of the CVEMP in which the stimulation rate was increased in order to complete the test in a shorter time span, making it more tolerable. In current literature the majority of studies use a stimulation rate of $5 \mathrm{~Hz}$. This means that five acoustic stimuli were presented each second in order to elicit a cVEMP response. In our study we increased the stimulation rate to $13 \mathrm{~Hz}, 13$ acoustic stimuli per second. By doing this, the test time was reduced by $40 \%$. We did find that the peak to peak amplitude was reduced, however these did not alter the threshold measured in healthy subjects. Since the substantially less time and thereby effort needed to complete the test we advise to use $13 \mathrm{~Hz}$ as stimulation rate.

The cVEMP is a relatively new test that has the ability to evaluate one of the parts of the balance organ that was

previously not possible. This

thesis demonstrates

the effect of 
normalization in CVEMP's and which method is most effective. Outcomes of the test will reflect saccular function more adequately and increase its clinical use. Further studies to the development of automated response recognition are already underway. Increasing stimulus rate can aid in reducing test burden without compromising test outcome. In monitoring Meniere's disease the cVEMP can play a role, for instance in evaluating before deciding whether or not to start more invasive treatment (intratympanic gentamicine or labyrinthectomy). Also in differentiating between Meniere's disease and vestibular migraine, the CVEMP can play a role. Further studies will have to show the role of cVEMP in diagnosing different vestibulopathies. But first standardization of the test should be the goal and with this thesis that goal has come closer. 
Summary | 133 



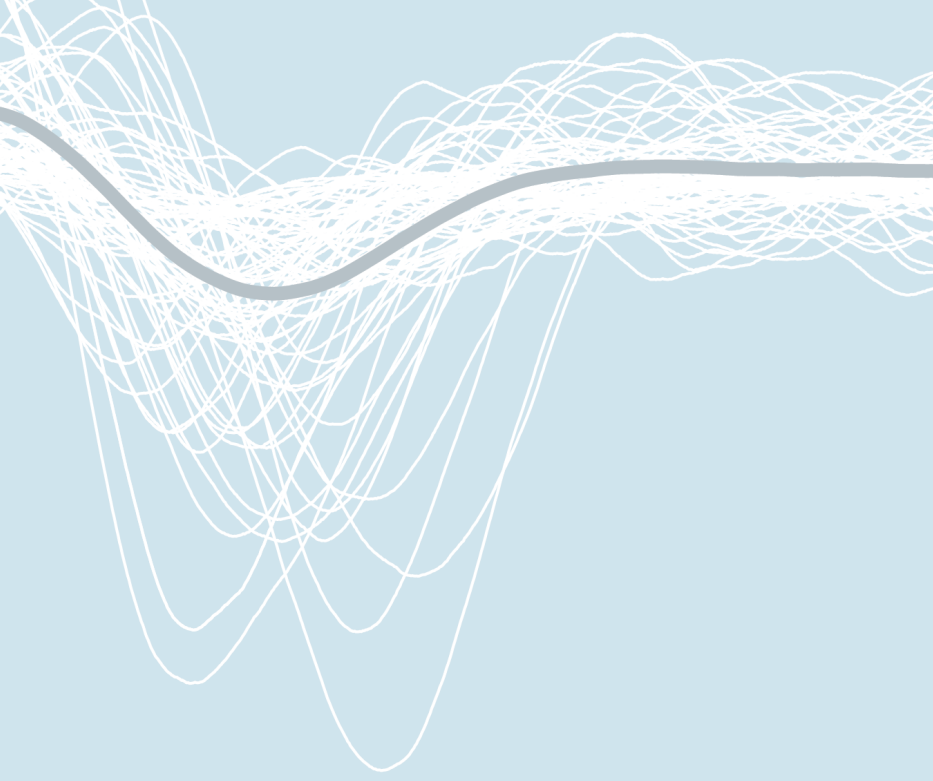

\section{CHAPTER 8}

Dutch summary (Nederlandse samenvatting) 
136 | Chapter 8 


\section{DUTCH SUMMARY \\ (NEDERLANDS SAMENVATTING)}

Wanneer een patiënt met duizeligheidklachten een KNO-arts bezoekt omvat een typische evaluatie veelal: een zorgvuldige anamnese, lichamelijk onderzoek, audiometrisch onderzoek en soms een ENG of beeldvormende diagnostiek. Hiermee worden het middenoor, de cochlea en het horizontale semicirculaire kanaal geëvalueerd. Het evenwicht systeem bestaat echter uit meer dan alleen het horizontale semicirculaire kanaal, maar het aantal testen wat dat onderzoekt is beperkt. Dit is in het bijzonder een probleem bij de diagnose van vestibulaire aandoeningen die zich buiten het horizontale semicirculaire kanaal bevinden, zoals bijvoorbeeld bij de ziekte van Ménière en bij superieure kanaal dehiscentie (SCD). De cervicale vestibular evoked myogenic potential (CVEMP) is een test die een uitspraak kan doen over een ander deel van het evenwicht systeem, namelijk de sacculus.

CVEMP's beschrijven de akoestische gevoeligheid van cellen in de sacculus. Deze cellen worden gestimuleerd door een luide akoestische stimulus aan te bieden in het oor aan de te testen zijde. De uitkomst van de test kan onder andere worden gemeten via een aangespannen musculus sternocleidomastoideus (SCM) aan ipsilaterale zijde die met elektromyografie gemonitord wordt. Door middel van inhiberende signalen die de sacculus naar de spier zendt wordt, na middelen van meerdere stimuli (meestal rond de 200-300 akoestische stimuli), de karakteristieke CVEMP vorm gezien op het electromyogram (EMG). De test krijgt in de huidige literatuur vrij veel aandacht omdat het een voorheen niet te testen onderdeel van het evenwichtsorgaan onderzoekt.

Het doel van deze thesis was om de klinische toepasbaarheid van de cervicale CVEMP te verhogen en dit heeft geleid tot de volgende vraagstellingen waarvan in onderstaand hoofdstuk een beknopt antwoord gegeven zal worden:

- Wat is de huidige state of the art in electrofysiologische testen voor de diagnose van de ziekte van Ménière?

- Hoe kan de intersubject variabiliteit van cVEMP's gereduceerd worden?

- Kunnen genormaliseerde cVEMP's progressie van de ziekte van Ménière over tijd aantonen?

- Is het mogelijk de cVEMP test praktisch beter uitvoerbaar te maken?

In hoofdstuk 2 werd een verkennend literatuur onderzoek gedaan naar de verschillende vestibulaire testen die de ziekte van Ménière evalueren omdat dit één van de meest voorkomende vestibulopathieën

is waarbij de cVEMP gebruikt

wordt. Naast de cVEMP,

werd gekeken naar electrocochleo- 
grafie (ECOG) en de Cochlear Hydrops Analysis Masking Procedure (CHAMP). Voor ECoG werd gevonden dat het een bruikbare test zou kunnen zijn in de vroege stadia van de ziekte. ECoG heeft echter een lage negatief voorspellende waarde waardoor deze test maar in weinig centra wordt uitgevoerd. Het feit dat de test niet meer uit te voeren is wanneer de patiënt gehoordrempels van boven de $60 \mathrm{~dB}$ heeft, is daarnaast een praktisch probleem wat de diagnostische mogelijkheden verder beperkt. De CHAMP gebruikt een onderdeel van de auditory brainstem reponse (ABR) om de snelheid (= de latentie tijd) van het signaal door de cochlea te meten warrbij de hypothese is dat de latentietijd toeneemt indien de ziekte verergert. Deze test meet de functie van de cochlea, warbij bij patiënten met vergevorderde en actieve ziekte een sensitiviteit en specificiteit van 100\% werd beschreven. Echter wanneer deze test werd verricht onder een meer diverse Ménière populatie werd een sensitiviteit van slechts 31\% gevonden en een specificiteit van $28 \%$. Verder is het geen vestibulaire test omdat het de functie van de cochlea meet. De kracht van deze test is om bij actieve en ernstige patienten de diagnose van Ménière te ondersteunen, echter als diagnosticum lijkt de test van beperkte waarde. Voor de cVEMP werd gevonden dat het gebruik van deze test geen plug en play is. Nauwkeurige voorbereiding en uitvoering zijn nodig om betrouwbare test uitslagen te verkrijgen, waarbij deze in de huidige literatuur maar zeer beperkt beschreven zijn. Daarbij is de onderliggende fysiologie en de optimale uitvoering en interpretatie van de resultaten nog niet gestandaardiseerd. Meer onderzoek is nodig om te bepalen hoe de cVEMP het best kan worden ingezet ter ondersteuning en monitoring van de ziekte van Ménière en andere perifere vestibulopathieen.

Een van de belangrijkste tekortkomingen van de cVEMP is de afhankelijkheid van spierspanning waardoor de variabiliteit van de test groot is. Het belangrijkste doel van deze thesis was het verminderen van de invloed van spierspanning op de uitslag van de cVEMP. Door te corrigeren voor de spierspanning (i.e. normaliseren) zou de variabiliteit van de test verminderden en een meer betrouwbare uitkomst geven. Hiervoor wordt in hoofdstuk 3 het principe van normaliseren toegepast op cVEMP's en wordt onderzocht met welke methode dit zo optimaal mogelijk verricht kan worden. In een prospectieve cohort studie met 20 jonge, gezonde proefpersonen werd het effect van normaliseren op de variabiliteit in uitkomsten tussen de proefpersonen onderzocht. Door te corrigeren voor de hoeveelheid spierspanning (= normaliseren) is het gelukt om, in gezonde proefpersonen, een signifi-

\section{I38 | Chapter 8}


cant lagere variabiliteit te verkrijgen wat de betrouwbaarheid van de test verhoogd. Simpel gezegd houdt normalisatie in dat voor elke gemeten respons er een coëfficiënt gemeten wordt die maat staat voor de geleverde spierspanning waardoor de respons wordt gedeeld. Hierdoor is de invloed van spierspanning op de uitslag van de cVEMP verminderd, een persoon met een krachtige halsspier zal daardoor vergelijkbare uitslagen hebben met iemand die een minder krachtige halsspier heeft indien de sacculus functie gelijk is.

Het proces van normaliseren kan op verschillende manieren ingevuld en toegepast worden. Dat wil zeggen, er zijn verschillende parameters beschreven om de coëfficiënt te verkrijgen die maat staat voor de spierspanning. In hoofdstuk 3.2 hebben wij drie parameters benoemd die van invloed zijn om de coëfficient te bepalen. Dit zijn: de timing van de normalisatie (trace-by-trace of na het middelen van alle traces), het type EMG (root mean square of gerectificeerd) en de tijdsduur van het verkrijgen van de coëfficiënt (pre stimulus of gedurende de gehele meting). Door elke individueel gemeten trace gedurende de hele meting te gebruiken werd de variabiliteit van de cVEMP tussen personen substantieel gereduceerd. Indien een centrum geen mogelijkheid heeft om uitgebreide signaal processing toe te passen werd geadviseerd het pre-stimulus deel van het de gemiddelde EMG te gebruiken om de coëfficiënt voor normalisatie te verkrijgen.

Nadat het effect van normaliseren aangetoond was en de meest efficiënte methode beschreven was werd in hoofdstuk vier het klinisch gebruik van cVEMP verder onderzocht. Er werd voor 2 patiënten groepen, patiënten met de ziekte van Ménière en patiënten met vestibulaire migraine, onderzocht of het verloop van tijd invloed had op de uitkomsten van de cVEMP. Hierbij was de hypothese dat in de Ménière groep een progressieve verslechtering van de cVEMP te zien zou zijn omdat deze ziekte ook een progressief karakter heeft. Voor de vestibulaire migraine groep werd dit minder waarschijnlijk geacht. Over een gemiddelde tijd van 2 jaar toonde de aangedane zijde van de Ménière groep in elke patiënt dat er een significante verslechtering was opgetreden in zowel de peak to peak amplitude als in de drempel meting terwijl de onaangedane zijde stabiel bleef. Voor de vestibulaire migraine groep werd gevonden dat de cVEMP stabiel bleef in alle patiënten over de gemiddelde follow up van 2 jaar. Een tekortkoming van deze studie is het retrospectieve karakter en de kleine patiënten aantallen. Echter in elke individuele patiënt uit beide groepen werd dezelfde ontwikkeling gezien (achteruitgang bij Ménière en stabiel bij vestibulaire migraine). Omdat er waarschijnlijk in het verleden patiënten

met Ménière gediagnostiseerd zijn terwijl ze vestibulaire 
migraine hadden (een diagnose die pas veel recenter beschreven is) lijkt het ons nuttig om een uitgangs-cVEMP te verrichten bij patiënten met de verdenking op een van beide ziektebeelden zodat deze eventueel in de toekomst herhaald kan worden.

In de laatste studie (hoofdstuk 5) beschreven in dit proefschrift is gekeken naar de verbetering van de klinische uitvoerbaarheid van de CVEMP, in het bijzonder naar de verhoging van de stimulus snelheid zodat de test in kortere tijd te voltooien is en daarmee praktisch beter uitvoerbaar is. In de huidige literatuur worden in het overgrote merendeel van de studies stimulatie snelheden van $5 \mathrm{~Hz}$ beschreven, dit houdt in dat er vijf akoestische stimuli per seconde werden aangeboden aan de te onderzoeken zijde. In onze studie hebben we deze stimulatie snelheid vergeleken met een snelheid van $13 \mathrm{~Hz}, 13$ stimuli per seconde. Hierdoor zou de test tijd, indien drempelwaardes op meerdere frequenties onderzocht worden, met $40 \%$ verkort worden. We vonden dat de peak to peak amplitudes lager werden bij een hogere stimulatie snelheid maar dat dit geen effect had op de gemeten drempels. Het advies is dan ook om de cVEMP uit te voeren met een stimulatiesnelheid van $13 \mathrm{~Hz}$.

De cVEMP is een vrij nieuwe test die de mogelijkheid biedt om eerder niet te onderzoeken delen van het labyrint te evalueren. Deze thesis demonstreert het effect van normalisatie in CVEMP's en welke methode het meest effectief is. Uitkomsten van de test zullen op deze manier meer adequaat de sacculus functie reflecteren en de klinische bruikbarheid verhogen. Verder onderzoek naar de ontwikkeling van geautomatiseerde response herkenning is al onderweg. Daarnaast heeft het verhogen van de stimulatie rate ervoor gezorgd dat de last van de test verminderd kan worden zonder de uitslag negatief te beïnvloeden. Ook in het volgen van patiënten met de ziekte van Ménière lijkt de cVEMP een bijdrage te kunnen leveren, waarbij het ook een rol zou kunnen spelen in het besluit om meer invasieve therapie te verrichten (zoals intratympanale gentamicine of een operatieve labyrinthectomie). Eveneens kan er een bijdrage van de CVEMP in het onderscheid maken tussen Ménière en vestibulaire migraine. Verder onderzoek zal de rol van cVEMP in de diagnostiek van verschillende vestibulopathieën aan moeten tonen, maar eerst zal een gestandaardiseerde test methode moeten worden beschreven. Daar is met deze thesis een belangrijke stap in gezet. 


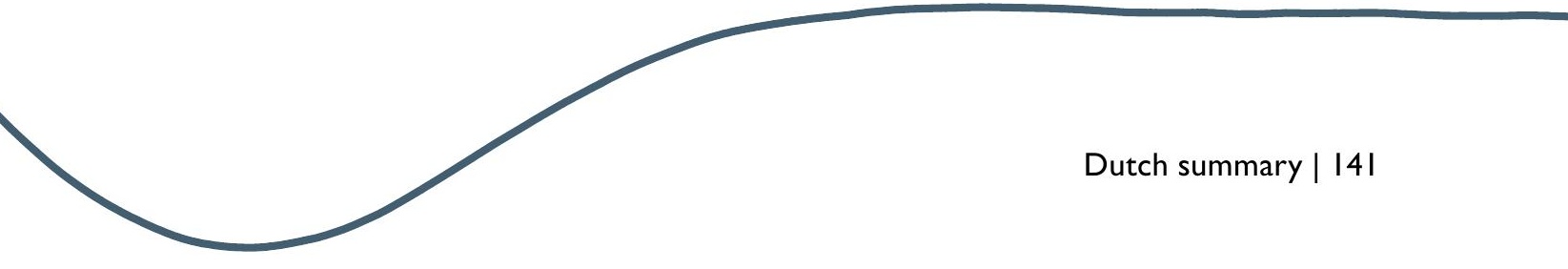

